\title{
Barriers to Primary Completion and Transition in Northern Nigeria: Evidence from a \\ Non-formal Schooling Intervention
}

\begin{abstract}
It is often claimed that the one-teacher, one-room, non-formal school model is more effective than the formal school in enrolling hard-to-reach children. This model is, however, not immune to the two-fold challenges of primary completion and transition. This article draws on data from three rounds of surveys with children from Tsangaya (traditional Quranic schools) in northern Nigeria who took part in a non-formal school programme. The article records project success in attracting children from Tsangaya schools and enabling them to complete the primary cycle. It shows that students' innate abilities and mother's education and income-generation ability seem to have a bearing on retention in primary school, while quality of teaching has an association with primary completion. However, it records major challenges to the transition to secondary school and argues for recognising the distinct challenges to primary completion and to transition from primary to secondary education.
\end{abstract}

Key Words: Non-formal education; primary completion; primary transition; Quranic schools; northern Nigeria. 


\section{Introduction}

How to get children from particularly vulnerable communities enrolled in primary schools? How to prevent them from dropping out and to successfully pass the primary completion exam? How to facilitate these children's transition to junior and senior secondary schools? These challenges continue to dominate the international education and development agenda (UNESCO 2015). This article draws on learning from an eight-year (2008-2016) non-formal schooling intervention in Kano, northern Nigeria. It shows that the core principles of the nonformal schooling model as widely applied today by development agencies did work, even in this challenging context and even in the absence of strong NGO capacity. ${ }^{1}$ Children from Tsangaya schools, a centuries-old Quranic schooling system, were successfully enrolled, despite the popular perception that the parents sending their children to these schools and the malams (religious teachers) are opposed to modern education. The majority of these children were successfully retained for the four-year condensed primary-education cycle, and passed a centralised state-run primary exam at the end of the programme (KERD 2014). However, ensuring actual transition to junior secondary schools, and retention therein, proved to be a challenge. This was not due to expected differences in the teaching methods and the environments of the non-formal schools and the government junior secondary schools, but due to much more fundamental institutional and economic challenges: difficulty in securing an official school-joining instruction letter from the State Universal Basic Education Board (SUBEB); distance from school; and an inability to pay school fees and purchase the necessary uniforms.

\footnotetext{
${ }^{1}$ The non-formal primary-schooling model is traditionally associated with NGOs. In the intervention under review, the non-formal schooling programme was, however, implemented through the primary-education regulatory authority.
} 
Further, comparing the survey responses of children who dropped out of the primary cycle with those of children who completed the primary cycle, the article argues that individual characteristics, mainly age at the time of joining the non-formal school and innate abilities, play a part in ensuring completion; more children who reported finding the studies challenging dropped out before completing the primary cycle. Household characteristics, including family income, showed no correlation with the ability to complete the primary cycle, given the limited variation in income levels within the population covered by this nonformal schooling intervention.

The above findings are in line with existing evidence that non-formal school models are particularly effective in educating hard-to-reach populations that for various reasons cannot follow the formal state schooling cycle. It also highlights the need to recognise the differing challenges to ensuring primary completion and transition that are encountered in particularly challenging contexts. Primary completion can be increased with improvements in teaching methods and developing curricula in response to the age of the students; successful transition to secondary, however, requires more systematic changes in the governance of the state schooling system.

This article has the following sections. Section 1 reviews the literature on the non-formal schooling model and notes how the model is widely supported by development agencies to access particularly hard-to-reach children in developing countries, as well as in post-conflict states; it also notes the growing interest within development agencies in working with Islamic and Quranic schools in contexts where the state's ability to provide primary education to all is particularly weak. Section 2 introduces the context of northern Nigeria and the extreme educational challenges that states there face in meeting the Education for All targets. Section 
3 explains the research design. Section 4 presents results from a survey conducted in 2014 with the 1,032 children who took part in the non-formal school intervention under study. The intervention was a collaborative effort between the UK government's Department for International Development (DFID) and the Kano state government. Implemented four years after the initial launch of the model, the survey covered the children still in school, as well as tracing those who had dropped out. Section 5 presents results from probit analysis to identify the factors that helped children to prepare to take the government primary-transition exam; the results show that completing the full four-year condensed primary-education cycle developed by the programme had a stronger correlation with passing the exam than any other factor. Section 6 presents the conclusions.

\section{Section 1. Non-formal schooling model and Islamic and Quranic schools: the background}

A one-room, one-teacher, non-formal schooling model whereby a teacher recruited from within the community and trained in child-centred learning methods educates a multi-grade class and prepares the children to take the primary transition exam in a period shorter than the standard government primary-schooling cycle is familiar to all development agencies today (USAID 2012; UNICEF 2014). Often also referred to as community schooling, the model is seen to be particularly effective in educating hard-to-reach children (girls in conservative societies, working children, minorities living in borderlands, nomadic populations, etc.); it is also viewed as integral to rebuilding education sectors in fragile states (Mfum-Mensah 2003; Rose 2009; USAID 2012; UNICEF 2014). Associated with a strong NGO presence, the model, as popular today, draws heavily on the educational programme of the Bangladesh 
Rural Advancement Committee (BRAC). ${ }^{2}$ Another core feature of the model is its flexibility: school hours are set in consultation with the community, to adjust to children's working needs. Cost is kept low by recruiting a teacher from within the community who has only an eighth- or tenth-grade qualification and is paid a small monthly allowance instead of a proper salary. Table 1 presents the key features of this model.

Table 1: Key features of the non-formal schooling model

\begin{tabular}{|l|l|}
\hline No. & Key Features \\
\hline 1 & $\begin{array}{l}\text { Teacher is from within the community } \\
\text { child-centred teaching methods }\end{array}$ \\
\hline 3 & $\begin{array}{l}\text { Hours are flexible and adjusted to fit around other commitments that the children } \\
\text { might have }\end{array}$ \\
\hline 4 & $\begin{array}{l}\text { Costs are low (teachers receive a token payment, not a proper salary; the } \\
\text { community provides the venue) }\end{array}$ \\
\hline 5 & \begin{tabular}{l} 
Focus is on promoting active learning, using child-centred teaching techniques \\
\hline
\end{tabular}
\end{tabular}

Although the model is widely utilised, research on it remains scarce (Dang, Sarr and Asadullah 2011; Gee 2015). As in the case of low-fee private schools, assertions that children in community schools learn better than in government schools are rarely rigorously tested (Ashley et al. 2014; Gee 2015). Further, we still know very little about what factors make some children successfully transition to junior secondary schools after studying in these non-

\footnotetext{
${ }^{2}$ For details of BRAC model and its impact, see Nath, Sylva and Grimes 1999. http://www.unesco.org/uil/litbase/?menu=4\&programme $=28$
} 
formal schools while other children drop out. Similarly, little attention has been paid to understanding whether the model poses different challenges and opportunities in rural and urban contexts. These questions are indeed not unique to this model, as they also apply to state schools and low-fee private schools in most developing countries (Ashley et al. 2014; UNSECO 2015). Learning about these issues in the context of one type of schooling model can therefore also arguably help to illuminate the issues for the other types of school.

We also know very little about the degree to which this model is effective in attracting children from Quranic and Islamic schools, despite the fact that within development agencies there is growing interest in engaging with these schools in those Muslim contexts where the state's capacity to provide basic education is very weak (Bano 2010). Children in these schools often receive no modern education, a fact which renders them vulnerable in terms of Education for All targets. Yet there is evidence that partnerships formed with these schools can be particularly cost-effective in imparting modern education to children from conservative Muslim communities (Bano 2010; Bah-Lalya 2015). Since these schools already have facilities and a student population, working with them saves the state and donor agencies the costs of mobilisation and providing infrastructure. Promoting integrated education programmes among Islamic and Quranic schools thus remains an important area of policy interest for governments in many countries, including Nigeria, where in the northern states there is a long history of Islamic and Quranic schools which outnumber state schools (Adamu 2010; Baba 2011). These schools were the main provider of education in the pre-colonial states of northern Nigeria (Adamu 2010; Baba 2010). We thereby need more research to understand how non-formal school interventions can be effectively developed for the student populations of Quranic schools (Asadullah and Chaudhury 2009; Bano 2010). 
Finally, research is lagging in another area. Despite widespread use of this model, there is no systematic study to see whether this one-room, multi-grade teaching model has consequences for the long-term learning ability of the children when they do transition to formal school at middle and secondary levels. Continued support for this model needs to be based on evidence that children taught in this model do not face any exceptional challenges when they enter the formal schooling system. The evidence presented in this article helps to inform these questions.

\section{Section 2. Schooling landscape and intervention details}

There are today few contexts more challenging than northern Nigeria for meeting EFA targets (Antoninis 2014; UNICEF 2017). It houses the largest share of the world's out-of-school children. State schools cannot match the demand, and the children enrolled in them show low learning outcomes (GPE 2014; UNICEF 2017). Low-fee private schools, now seen also to be catering to the poor in many developing countries (Ashley et al. 2014), are estimated to cater to less than 8 per cent of the school-age population in Kano (MoE 2010). Understanding the specific challenges posed to education in this context, and identifying strategies that might help to mitigate them, is therefore a priority concern for international development agencies.

Kano, the most densely populated state in the north, shares similar challenges to ensuring universal access to primary education and improving the quality of learning (MoE 2010). In addition to supply-side failures, religious resistance to modern education is seen as a major challenge to meeting the EFA targets. Historically, modern schools are seen as a legacy of colonial rule. Although these schools are now accepted as the main route for economic mobility, within religious circles there is argued to be continued resistance to modern education. This ideological resistance is most commonly associated with the Tsangaya 
schools, a centuries-old male Quranic schooling system, in which a child focuses almost exclusively on memorisation of the Quran, followed by learning to write the Quranic script. The 1960s and 1970s saw the birth of Islamiyya schools, which combine modern and Islamic education (Umar 2001; Umar 2003); but Tsangaya schools did not follow the same model, choosing instead to preserve their traditional focus on reading, memorising, and learning to write the Quran in Arabic. The whole learning process takes up to seven years, although some students end up staying even longer (CUBE 2008; Baba 2011) ${ }^{3}$. Referred to as almajaris, the students in Tsangaya schools, who are all male, are seen to be particularly vulnerable, even within the overall schooling landscape in northern Nigeria, with all its challenges (CUBE 2008; Baba 2011). The age of children enrolled in them may range from 5 years to the midtwenties, although the average age among the children surveyed was 11 (see Table 2). Many have also to beg for food or money for daily survival. Table 2 captures the key characteristics of this population, based on the results of the baseline survey conducted with 1,032 children from 150 Tsangaya schools in 2011. These schools were mobilised to take part in the nonformal schooling intervention discussed in this article in three different LGAs in Kano.

Table 2. Selected characteristics of the Tsangaya student population

\begin{tabular}{|l|l|l|}
\hline No. & Characteristic & Response \\
\hline 1 & Average age & 11 years \\
\hline 2 & Average time at Tsangaya & 3 years \\
\hline 3 & Location of the family & 70 per cent of the children surveyed came from the \\
& & same community; yet 51.34 per cent reported \\
\hline
\end{tabular}

\footnotetext{
${ }^{3}$ The Capacity for Universal Basic Education (CUBE) programme, which preceded ESSPIN, was funded by DFID in Nigeria between 2003 to 2008.
} 


\begin{tabular}{|c|c|c|}
\hline & & $\begin{array}{l}\text { sleeping at a Tsangaya- or community-provided } \\
\text { space. }\end{array}$ \\
\hline 4 & Access to number of meals & $\begin{array}{l}\text { Most children reported securing access to three meals } \\
\text { a day. However, } 59.16 \text { per cent reported 'still feeling } \\
\text { hungry' after eating their meals. }\end{array}$ \\
\hline 5 & Father's background & $\begin{array}{l}98 \text { per cent of the children reported that their fathers } \\
\text { were alive; the majority were farmers. }\end{array}$ \\
\hline 6 & Mother's background & $\begin{array}{l}75 \text { per cent of the children reported that their mothers } \\
\text { were housewives; the key income-generating } \\
\text { activities mentioned were the sale of traditional food } \\
\text { and sewing. }\end{array}$ \\
\hline
\end{tabular}

The Islamic and Quranic schools in northern Nigeria are important not only because they attract some of the poorest children, but also because of their large number (CUBE 2008; Antoninis 2014). In Kano state, only 47 per cent of school-age children are enrolled in state primary schools, yet more than 89 per cent of children are estimated to attend some kind of Islamic or Quranic school (CUBE 2008). A 2003 census of Islamic and Quranic schools recorded 23,000 schools (CUBE 2008), compared with 6,000 state primary and secondary schools. ${ }^{4}$ Enrolment in Tsangaya schools, however, does not contribute to basic numeracy or literacy in a formal sense, ${ }^{5}$ as learning in these schools focuses purely on the memorisation of

\footnotetext{
${ }^{4}$ Data provided in a 2016 interview with the Ministry of Education.

${ }^{5}$ UNESCO's definition of literacy has moved 'from viewing literacy as a simple process of acquiring basic cognitive skills, to using these skills in ways that contribute to socio-economic development, to developing the capacity for social awareness and critical reflection as a basis for personal and social change' (UNESCO 2006).
} 
the Quran in Arabic. Yet Tsangaya schools remain very popular with parents in the north. Federal as well as northern state governments have made efforts to provide modern education to children in Tsangaya schools, who in terms of structural inequalities are the most deprived within an overall extremely challenging context. Such efforts have, however, had limited success.

In 2010, with the support of a large bilateral education programme (Education Sector Support Programme in Nigeria, ESSPIN), a four-year non-formal school programme was launched for children from Tsangaya schools which condensed the six-year primary school curriculum into four years ${ }^{6}$. It adopted all the standard features of the non-formal schooling model outlined above in Table 1. Malams of Tsangaya schools were mobilised to send their pupils to a nonformal school set up in a nearby location, where children were given education in accordance with the state primary-school curriculum. Further, a conscious decision was made to recruit children between the ages of 7 and 11 , on the assumption that they would be better able to cope with the condensed primary-education cycle. In order to understand the implications of rural and urban variations for the success of this programme, the programme was launched in three Local Government Authorities (LGAs are the equivalent of a district): Fagge (urban); Kumbotso (semi-urban); and Albasu (rural). As can be seen in Table 3, some LGA-level variations are obvious instantly. Albasu, the rural LGA, is spread out over a large area, due to its reliance on farming, and as a result it is much more thinly populated than the urban LGAs. This has major implications for monitoring capacity. Qualitatively, fieldwork in the three

\footnotetext{
${ }^{6}$ A similar intervention was also introduced with female students in Islamiyya schools, which offer both Islamic and modern subjects. This article, however, only focuses on results from the intervention in the Tsangaya schools.
} 
LGAs also revealed a clear difference in income levels, employment opportunities, availability of qualified teachers, and LGEA staff capacity across the three LGEAs.

Table 3: Geographical area and population per LGA

\begin{tabular}{|l|l|l|l|}
\hline LGA & Rural/Urban & Geographical Area & Population (2006 census) \\
\hline Fagge & Urban & $21 \mathrm{~km}$ square & 198,828 \\
\hline Kumbotso & Semi-Urban & $158 \mathrm{~km}$ square & 295,979 \\
\hline Albasu & Rural & $398 \mathrm{~km}$ square & 190,153 \\
\hline
\end{tabular}

In 2010, 1,032 children from 150 Tsangaya schools were enrolled in these non-formal schools set up under the programme. This first group of children was referred to as Cohort 1. In April 2014, i.e. four years later, 679 children from the first cohort in Kano took the centrally administered state primary-transition exam, and 97 per cent passed with impressive scores (KERD 2014). Further, in 2016, 326 of these children could be traced in government junior secondary schools (Grades 7-9). A number of features of this intervention make it particularly conducive to enriching our learning. First, the intervention was implemented entirely through government education authorities at the state and local government levels-the State Universal Basic Education Board (SUBEB) and the Local Government Education Authorities (LGEA) respectively - instead of NGOs. Thus, officials from state agencies could make this model work, even though the state education sector continues to suffer from severe challenges (Antoninis 2014). Further, the children exposed to this intervention not only came from a particularly vulnerable population: they also had the dual burden of carrying on with their Quranic education in addition to their primary education and were required to complete the six-year primary cycle in four years of study with teachers who themselves had only $8-10$ years of education. These teachers were paid a very small monthly stipend. Yet 97 per cent of 
those who completed the non-formal school programme passed the state primary-transition exam. The results from this intervention thus help us to explore two key questions: one, what explains the success of those who completed the programme?; two, what factors led close to 36 per cent of children to drop out before completing the primary cycle?

\section{Section 3. Methodological framework}

This article draws on a close study of this intervention between 2008 and 2016. During this period, I conducted interviews and ethnographic fieldwork with Tsangaya school children, SUBEB and LGEA staff, and the community teachers recruited to teach in the non-formal schools. In addition, I designed three rounds of surveys with the children from Cohort 1 (see Table 4). A baseline survey was conducted in 2011 with a total of 1,032 children who were initially enrolled in the 30 non-formal schools opened across the three LGAs. This baseline survey documented the basic socio-economic profile of each child, his educational preferences, individual characteristics, and relationship with the Quranic school teacher. The baseline survey had two objectives: one, to record any major socio-economic variations in the profile of the children enrolled; two, to help monitor how many of these children would actually complete the four-year primary cycle.

In 2014, a follow-up survey was designed and implemented with all the children who were still in school. Since the school teachers were allowed to take on new children to fill spaces left by a dropped-out child, the school population surveyed contained both children from the baseline population and those who had joined later. The inclusion of these new children allowed for a variation in the joining date. This is very important for our analysis, because, as we will see in the results from the probit analysis presented in Section 5, this variation in the children's joining dates bear a strong correlation to a child's ability to pass the primary- 
transition exam. A comparison of the children taking part in the surveys in 2011 and 2014 confirmed that 612 (60 per cent) of the original children enrolled in 2011 had actually stayed in school until 2014. Further, 58 new children had appeared in the second round. The 2014 survey also tried to trace as many as possible of the 420 children who had dropped out, using a slightly modified version of the questionnaire implemented for those still in school. The survey team was able to trace 210 (50 per cent) of the dropped-out children. With the children still in school, the survey was conducted over one week during July 2014; in addition, enumerators were allowed a month for tracking the children marked on the school register as having left.

Finally, a third survey was implemented in 2016 with the 670 children who had passed the government primary-transition exam successfully in 2014 , to see how many had actually entered the junior secondary schools, and how those who were still in school were actually coping. The survey team attempted to trace as many of these 670 children as possible. The short questionnaire aimed to understand the possible reasons why children might not transition to secondary school even after passing the transition exam.

Table 4: Survey rounds, objectives and student numbers

\begin{tabular}{|l|l|l|l|l|}
\hline No & Year & Objective & Category & Numbers \\
Raseline & & profile of students enrolled & non-formal schools & \\
\hline Round 2 & 2014 & $\begin{array}{l}\text { See how many are in the non- } \\
\text { formal school four years on, } \\
\text { and what factors influence }\end{array}$ & Population 1: Still in & P1: 612 \\
& & Population 2: Drop-outs & P2: 210 \\
\hline
\end{tabular}




\begin{tabular}{|l|l|l|l|l|}
\hline & & drop-out & who could be traced & \\
& & Population 3: New & P3: 58 \\
Round 3 & 2016 & $\begin{array}{l}\text { Trace the 670 children who } \\
\text { passed primary in 2014, to see } \\
\text { how many are in secondary } \\
\text { school }\end{array}$ & Those who could be & 428 \\
& traced & \\
\hline
\end{tabular}

\section{Section 4. Rural-urban variation and reasons for dropping out}

Tracing the children from Cohort 1 shows that, as has been proven in many other challenging contexts, under the non-formal schooling model children could pass the six-year primary cycle in four years. Interestingly, the model proved most effective in the rural LGA, even though, in line with evidence from other developing countries, education in the rural LGA faced more extreme challenges (Antoninis 2014; MoE 2008 and 2010). Fieldwork showed that the LGEA staff capacity in Albasu, the rural LGA, was weakest. On the other hand, Fagge, the urban LGA, recorded the greatest variation in results, even though it also hosted the highest-performing school, with an average exam score of 78.27 per cent (see Table 5).

Table 5. Average school performance per LGA

\begin{tabular}{|l|l|l|l|}
\hline LGA & Rural/Urban & $\begin{array}{l}\text { Average student exam scores per school } \\
\text { in 2014 state primary-transition exam }\end{array}$ & $\begin{array}{l}\text { Levels of } \\
\text { variation in } \\
\text { results }\end{array}$ \\
\hline Fagge & Urban & $36.47 \%-78.27 \%$ & Most \\
\hline Kumbotso & Semi-Urban & $58.44 \%-70.63 \%$ & Medium \\
\hline
\end{tabular}




\begin{tabular}{|l|l|l|l|}
\hline Albasu & Rural & $60.25 \%-74.41 \%$ & Least \\
\hline
\end{tabular}

Source: KERD 2014

Drawing on observations and fieldwork across the three contexts, it appears that the main reason for high drop-out rates and high school variation in the urban areas as opposed to the rural area is the existence of distractions. Children in the urban areas have more distractions in terms of entertainment. Second, parents or malams as guardians are more strongly tempted to send the children out to earn income, as more odd jobs are available in the urban areas. Finally, there could potentially be a difference in teacher commitment, as in the rural areas the teachers were more embedded in the community.

\section{Stated reasons for dropping out}

The Round 2 survey shows that out of the 210 children who were tracked from among those who had left the non-formal school, 20 per cent reported leaving due to moving out of the community. An equal percentage, as can be seen in Table 6, left because they had made a successful transition to a Junior Secondary School (JSS) in 2013, a year before completing the four-year condensed primary-education cycle. ${ }^{7}$ Another 20 per cent left because they had to provide for themselves or their families, thus making the cost of attending a modern school too high for them. A small percentage (5 per cent) also reported the school as being too far to reach on foot. Interestingly, only one student reported leaving because the malam told him to do so; thus ideological resistance did not prove a challenge for this model at any stage.

Table 6: Why did you leave the non-formal school?

\footnotetext{
${ }^{7}$ These children most likely had access to some modern schooling before being enrolled in the non-formal schooling programme.
} 


\begin{tabular}{|l|l|l|}
\hline Response options & Frequency & Percentage \\
\hline Moved away from this community & 44 & 21 \\
\hline I was not interested & 13 & 6 \\
\hline Difficult to follow lessons & 20 & 9.5 \\
\hline School too far to walk & 10 & 5 \\
\hline I had to provide for myself & 24 & 11 \\
\hline I had to provide for my family & 18 & 9 \\
\hline Malam told me to leave & 1 & 0.48 \\
\hline Joined a Junior Secondary School (JSS) & 40 & 19 \\
\hline Other & 40 & 19 \\
\hline Total & 210 & 100 \\
\hline
\end{tabular}

Source: Own survey data, Round 2.

Out of the 20 per cent of children who reported moving to a new community, close to 35 per cent reported the need to help the family as the main reason for moving away from the host community. Another 15 per cent reported joining a different malam as the primary reason for moving. In addition, 22 per cent reported moving in order to join a regular primary school. Also, assistance needed on the family farm was reported by some as a main reason for a family to call a child back.

\section{Additional observations}

The socio-economic profile of the children who dropped out when compared with that of those who stayed in school to complete the primary cycle revealed some interesting results. Of those who had left, the majority ( 52 per cent) reported their fathers to be farmers, while 30 per cent reported them as being businessmen/traders. The responses from children still in 
school were very similar: 48 per cent reported their fathers to be involved in farming, while 23 per cent reported their fathers as running a business. We therefore see little variation in the fathers' occupational backgrounds. There was, however, a difference in the reported profile of the mothers. Of those who had left, 67 per cent reported their mothers to be housewives, compared with only 40 per cent of the children who were still in school. Also, 37 per cent of those still in school reported their mothers as being involved in trading or selling, compared with only 19.41 per cent of those who had dropped out. These results suggest that maternal engagement in income-generating activities can improve a child's attendance in a modern school.

\section{Reasons for irregular attendance}

Close to 40 per cent of the students (both leavers and those who completed the primary cycle) reported being irregular in attending the non-formal school. This was expected given that the pupils in Tsangaya schools have to beg for food or run errands to generate income for daily survival. There was, however, an important difference in the main reason the children in the two groups noted for irregular attendance. Twenty-seven per cent of those who dropped out chose the response option (I found it difficult to follow the lesson), while only 7 per cent of those who completed the primary cycle selected this option (see Table 7).

Table 7: Reasons given for irregular attendance $(\%)$

\begin{tabular}{|l|l|l|}
\hline Response options & Leavers & Remainers \\
\hline I was not interested & 7 & 4 \\
\hline I found it difficult to follow the lesson & 27 & 7 \\
\hline School was too far to walk & 7 & 13 \\
\hline
\end{tabular}




\begin{tabular}{|l|l|l|}
\hline I had to work to buy my food & 10 & 10 \\
\hline I had to beg for food in the community & 9 & 6 \\
\hline I had to beg for money on the street & 2 & .3 \\
\hline Malam told me not to go & 1 & 1.37 \\
\hline
\end{tabular}

Source: Own survey data, Round 2

In both the groups, more than 60 per cent of the children reported finding it difficult to catch up when they returned to school after being away for a couple of days. Close to 64 per cent of children from both the groups reported asking the teacher to help them to catch up. In addition, 80 per cent of the children who had left and 63 per cent of children still in school reported asking other students to help them to catch up. Only 6 per cent of those who had left and 17 per cent of those still in school said that they studied the missed course by themselves. Over 90 per cent of students in both the populations reported still pursuing Quranic education. It thus appears that the child's personal calibre and commitment remains an important factor in determining the ability to finish primary education.

\section{Section 5. Ability to pass the primary-transition exam: results from a regression analysis}

While the above section identifies the factors that seem to shape a student's ability to stay in school over a four-year primary cycle within a very poor population in northern Nigeria, this section briefly explores the evidence to assess the factors that enabled some children to pass the primary-transition exam in 2014. Such an analysis was possible because, as outlined in the Method section, in 2014 the 30 schools had a total of 750 students on the register, but not all of them were from the original cohort recruited in 2010: new children were added to replace those who had dropped out, in order to ensure optimal use of the resources invested in the intervention. Using an internally administered mock exam to differentiate between the 
children ready to take the transition exam and those not ready made it possible to assess if any of the following factors could have influenced this outcome ${ }^{8}$ : age of the child at the time of joining the non-formal school programme (children were enrolled between the ages of 8 and 12, although some children over this age were also accommodated); family income level; sleeping arrangements, given that most children sleep at a place provided by the malam or the community, while those from within the community normally sleep at home; number of years spent in the non-formal school programme by 2014; and rural-urban variations.

The key finding is that completing the four-year condensed primary non-formal school cycle had a direct bearing on a student's ability to take the primary-transition exam. This suggests that condensing the primary schooling cycle into a four-year cycle is feasible; however, reducing the cycle to less than four years might not be feasible unless the children have had some prior access to modern schooling. ${ }^{9}$ This result supports existing studies which argue that pacing the curriculum according to the age of the children, plus improving teachers' skills to deal with children from different age groups, can improve student learning outcomes. Other variables that show a possible link with increased chances of success in the transition exam are age and sleeping at a place provided by the community, as opposed to one provided by the

\footnotetext{
${ }^{8}$ Only those children who passed the mock exam were made to take the primary transition exam which 97 per cent of these students passed. The mock exam results thus are used as a proxy for success at state primary transition exam.

${ }^{9}$ As mentioned earlier, a few students taking part in this four-year non-formal school programme had successfully taken the primary transition exam while they were in the third year, but they were small in number and most probably had some prior exposure to modern education. These children do not affect the results of the probit analysis, as they were not in the non-formal schools at the time of the survey in 2014.
} 
malam. Consistent with the qualitative observations, the slightly older children, i.e. those who joined when they were 10 years old as opposed to being 7 or 8 , perform better in this condensed non-formal schooling cycle. However, this relationship has a bell-shaped curve which means that after a certain age the relationship between age and ability to complete primary develops a negative association. These results again match the observations of the field team, because some of the older children (17 years plus), who were at times allowed to join on the insistence of a malam or due to their own expressed interest, did not perform very well in internal assessments. It seems probable that beyond a certain age children have more responsibility to earn a living and thus cannot focus on their studies, even if they are keen and

get involved. A possible association between student performance in the primary-transition exam and their sleeping location is surprising; it could be that those who sleep at a place provided by the community are also supported by some patrons within the community in some other ways which facilitate the learning process.

\section{Section 6. Challenges to secondary transition}

Responses from the 428 children in the Round 3 survey that aimed to trace the 670 children who had successfully passed the primary-transition exam in 2014 show that 76 per cent were still in school (Table 8). As can be seen in Table 8, out of the 428 children who were traced during the survey, 326 were still in the junior secondary schools. This means that, out of the total of 670 children who successfully completed the primary-school cycle under the nonformal schooling programme and had passed the primary-transition exam in 2014, 48.6 per cent were confirmed to be in the junior secondary school two years on from passing the transition exam. An examination of the response rate within the traced children reveals that the average retention has actually been quite impressive, i.e. 76 per cent. 
Table 8: Students in secondary school among the traced children

\begin{tabular}{|l|l|l|}
\hline Is the child in & Frequency & Percentage \\
secondary school? & & \\
\hline Yes & 326 & 76.1 \\
\hline No & 102 & 23.83 \\
\hline Total & 428 & 100 \\
\hline
\end{tabular}

As can be seen in Table 9, a large proportion (41.5 per cent) of the 102 children who are not in school attributed it to the failure to secure school-joining instructions from SUBEB. This was due to overcrowding in state schools whereby there are not enough places in junior secondary schools to guarantee a seat for each child. Consequently, many students were not assigned to any junior secondary school, despite the children and their families trying to secure this admission. For poor parents, especially in rural communities, securing the schooljoining instructions for their children without support thus remains a serious challenge. The second major reason for dropping out after joining the junior secondary school was the distance from the school: 12.7 per cent of the children reported this to be the key challenge. This challenge was also recorded in many of the qualitative interviews. The junior secondary school to which a child was assigned was often too far away, and the child's family or the malam did not have the money to cover the public-transport cost. Especially in the case of female students, distance also created security concerns.

The cost of admission and the tuition fee imposed by some JSS schools, even when officially these costs are not allowed, restricted the access of close to 5 per cent of the children 
surveyed. It is to be noted that this figure is relatively small in the reported data, mainly because under the intervention some of the children received support to cover these costs. In future years without this financial support, for many of these children these recurrent costs will become a potential cause of drop-out.

Another 7 per cent of the children reported the lessons being too difficult, while 4 per cent noted that they did not like the style of teaching in the junior secondary school. Only 7 per cent reported dropping out due to finding the education in junior secondary schools as being challenging. The children who passed the primary-transition exam with low scores can be expected to struggle in junior secondary schools, especially those from families where no one was educated. The fact that only 4 per cent of children recorded challenges in adjusting to the style of teaching in the junior secondary school shows that the difference in school environment did not have a major impact on successful transition. Qualitative interviews conducted with these children supported similar results.

Table 9: Main reasons for failed transition to JSS

\begin{tabular}{|l|l|l|l|}
\hline No. & Reasons for leaving & Frequency & Percentage \\
\hline 1. & Did not get the school-joining & 49 & 48 \\
\hline 2. & Did not have the money to pay & 1 & 1 \\
\hline 3. & Did not have the money to buy & 5 & 5 \\
\hline 4. & Did not like the teaching method & 5 & 5 \\
\hline
\end{tabular}




\begin{tabular}{|l|l|l|l|}
\hline 5. & Found the lessons very difficult & 8 & 8 \\
\hline 6. & The JSS school was too far & 15 & 15 \\
\hline 7. & Did not have the books and the & 2 & 2 \\
\hline 8 & teaching materials & & 17 \\
\hline
\end{tabular}

\section{Conclusion}

The lessons from this intervention are useful both for understanding the specific educational challenges in northern Nigeria and for addressing some broader questions about primary completion and transition. The article has illustrated that a non-formal schooling model can work in the most disadvantaged of communities and without strong NGO capacity, given that this particular intervention was implemented through the Local Government Education Authorities (LGEAs), the lowest tier of education implementation in the Nigerian education system. This is important to note, as often a strong NGO culture is deemed to be an essential prerequisite for the success of a non-formal schooling programme. This case showed that capacity for running such programmes can be easily built within the state agencies.

Second, the article has shown that the challenges to primary completion are different from the challenges to successful transition to junior secondary. In ensuring primary completion, maternal education and income-generation ability seem to play some role. Other factors appear to be the calibre of the student and the provision of flexible teaching hours. Further, the success of the model highlights the importance of developing age-responsive curricula: the children in this intervention were slightly older than their peers in regular state schools at 
the time of starting the primary cycle and thus could cover the same curriculum in a shorter time. Here it is important to remember that these results draw on surveys of students enrolled from Tsangaya schools. The success of the intervention in enabling children from these schools to complete the primary-education cycle thus also confirms that ideological resistance is not the main hurdle restricting the access of children to modern education. Rather, a model offering flexible teaching hours that allow the children from Quranic schools to carry on with their Quranic learning but also be part of a modern school can guarantee these children's access to modern education.

Challenges to the transition from primary to secondary education are, however, more institutionalised. Resource constraints limit the state's ability to open more secondary schools, with the result that securing a government letter to join a state junior secondary school becomes a major challenge. The more rural the LGA and the more poor the parents, the more challenging it becomes to secure this access. Further, many state schools ask for admission fees even when officially in Nigeria education is free in state schools. Some parents struggled to pay this fee, while others struggled to afford the cost of the uniforms. Books were meant to be free, but again the reality was different. While this article draws on the results of a survey of children participating in the non-formal school intervention, but given that only $22 \%$ of the total eligible children are enrolled in a junior secondary school in Nigeria (UNICEF 2017), it would suggest that these challenges are not specific to this group; rather they apply across the board.

The results from this study are not surprising, but by identifying different challenges to primary completion and the challenges to transition from primary to junior secondary schools the article hopes to highlight how addressing these two concerns requires different 
interventions. Also, further research is required to assess the cost-effectiveness of the nonformal schooling models vis-à-vis the state schools. As non-formal schools offer only a small monthly stipend to the teachers, instead of a proper salary, and as they operate in spaces offered by the community, they are assumed to be more economical than the state schools. This assumption is further supported by the fact that these schools condense the six-year primary cycle into four years. However, running these non-formal programmes incurs some additional costs, such as heavy investment in the training of community teachers and the provision of incentives to the communities, or in this case the malams. Further studies of the non-formal schooling model should therefore also attempt to compare the relative costeffectiveness of the two models.

\section{Technical Annex}

Factors Determining Whether a Student Takes the Primary Transition Exam

\section{DATA AND VARIABLES}

Data set: Tsangaya

Observations: 611

Dependent Variable: The key dependent variable is Primary_Transition_Exam, which takes the value 1 if an individual has taken the primary transition exam and 0 otherwise. 
$\underline{\text { Key Explanatory Variables }}$

- Age

- Family Income Level: Discrete variable where 1 is 'very poor' and 5 is 'very rich'

- Sleeping Arrangement: This is a discrete categorical variable where the categories do not represent any particular ascending or descending order. Dummy variables have been created for each of the categories, which take on the value 1 if the 'sleep at night' variable is reflecting that category and 0 otherwise. The dummy for sleeping in a Tsangaya has been excluded from the regression so that the rest of the dummies can be interpreted against the Tsangaya dummy. For example, the dummy for sleeping in the community can be interpreted as the impact of sleeping in the community on the PTS, as compared with sleeping in a Tsangaya. Furthermore, omitting one dummy from a group of dummies created from a single variable is important to avoid multicollinearity.

- Number of Years in Non-Formal School: This is a discrete variable that has been recategorised so that 1 represents 1 year and 4 represents 4 years.

- LGA: There are three LGAs, where 1 represents a rural LGA, 2 semi-rural, and 3 urban.

\section{$\underline{\text { Additional Explanatory Variables }}$}

- Number of Years in Tsangaya School: Varied answers (0, 2, 3 etc).

- Cable Network: Binary dummy variable where 0 is no and 1 is yes.

- Enough to Eat: Binary dummy variable where 0 is not enough to eat and 1 is enough to eat. 
- Non-Formal School Attendance: 1 is very regular attendance and 5 is very sparse attendance.

\section{BASIC SPECIFICATION AND RESULTS}

We can fit our probit model as such:

$\operatorname{Prim}_{-}$Exam $_{i}=X_{i} \beta_{1}^{\prime}+Y_{i} \beta_{2}^{\prime}+Z_{i} \beta_{3}^{\prime}+u_{i}$

Where Prim_Exam ${ }_{i}$ is a binary response variable describing whether individual $i$ took the primary transition exam or not. Our response variable is equal to 1 when the individual has taken the exam, and 0 otherwise. $X_{i}$ contains personal attributes of individual $i$. In the basic specification, this includes age, age ${ }^{2}$, number of years in ESSPIN school and LGA. $Y_{i}$ contains dummy variables for an individual's boarding arrangements. These include dummies for: (1) Sleeping in another place arranged by the malam, (2) Sleeping with parents, (3) Sleeping within the community, and (4) Other sleeping arrangements. The dummy for sleeping in a Tsangaya has been excluded from the regression, so that the rest of the dummies can be interpreted against the Tsangaya dummy. $Z_{i}$ refers to income attributes of individual $i$ 's family and income. In the basic specification, this includes an individual's perceived family income level. $u_{i}$ denotes the error term, and contains all other factors influencing whether an individual takes the primary transition exam that are not captured by the regression model.

\section{Results}

Table 1 represents the Probit results for the basic specification. The coefficients reported in column 1 are from the direct probit regression. The standard errors are reported under each 
coefficient. The significance level of each coefficient is represented by $* * *$ (significant at $1 \%$, i.e. p-value $<0.01), * *($ significant at $5 \%$, i.e. $0.01<$ p-value $<=0.05)$ and $*($ significant at $10 \%$, i.e. $0.05<$ p-value $<=0.1$ ). We report the marginal effects in Column 2, following the same format as above.

Table 1: Probit model of basic specification

\begin{tabular}{|c|c|c|}
\hline VARIABLES & $\mathrm{C}$ & $\mathrm{M}$ \\
\hline \multirow[t]{2}{*}{ Age } & $0.215^{* *}$ & $0.078 * *$ \\
\hline & $(0.084)$ & $(0.031)$ \\
\hline \multirow[t]{2}{*}{$\operatorname{age}^{2}$} & $-0.006^{* *}$ & $-0.002 * *$ \\
\hline & $(0.003)$ & $(0.001)$ \\
\hline \multirow[t]{2}{*}{ LGA } & -0.114 & -0.041 \\
\hline & $(0.082)$ & $(0.030)$ \\
\hline \multirow[t]{2}{*}{ Years in ESSPIN School } & $0.662 * * *$ & $0.241 * * *$ \\
\hline & $(0.095)$ & $(0.034)$ \\
\hline \multirow[t]{2}{*}{ Sleeping at malam's } & $-0.434 * *$ & $-0.146 * *$ \\
\hline & $(0.182)$ & $(0.055)$ \\
\hline \multirow[t]{2}{*}{ Sleeping at home } & 0.066 & 0.024 \\
\hline & $(0.130)$ & $(0.048)$ \\
\hline \multirow[t]{2}{*}{ Sleeping within community } & $0.799 * *$ & $0.310 * *$ \\
\hline & $(0.342)$ & $(0.128)$ \\
\hline \multirow[t]{2}{*}{ Sleeping, others } & 0.328 & 0.126 \\
\hline & $(0.763)$ & $(0.303)$ \\
\hline
\end{tabular}

Family income level

$-0.135 * \quad-0.049 *$ 


\begin{tabular}{lcc} 
& $(0.073)$ & $(0.073)$ \\
Constant & $-3.916^{* * *}$ & $-3.916^{* * *}$ \\
& $(0.788)$ & $(0.027)$ \\
& & \\
\hline Observations & 598 & 598 \\
Pseudo R-squared & 0.094 & \\
\hline
\end{tabular}

Robust standard errors in parentheses $* * * \mathrm{p}<0.01, * * \mathrm{p}<0.05, * \mathrm{p}<0.1$

$\mathrm{C}$ (Coefficient) and M (Marginal Effects)

\section{References}

Adamu, A.U. 2010. "Islamic Education in African Countries: The Evolution of Non-Formal Al-Muhajirun Education in Northern Nigeria.” Discussion paper presented at the workshop Islamic Education in African Countries, organised by Ensar Vakfi, Istanbul, 14-18 June.

Antoninis, M. 2014. "Tackling the Largest Global Education Challenge? Secular and Religious Education in Northern Nigeria." World Development 59: 82-92. 
Asadullah, M. N., and N. Chaudhury. 2009. "Holy Alliances: Public Subsidies, Islamic High

Schools, and Female Schooling in Bangladesh.” Education Economics 17 (3): 377-394.

Ashley, L.D. et al. 2014. “The Role and Impact of Private Schooling in Developing Countries." Education Rigorous Literature Reviews, Department for International Development (DFID), April 2014. Accessed 15 February 2017.

www.gov.uk/government/uploads/system/uploads/attachment_data/file/304440/Privateschools-2014.pdf

Baba, N. M. 2011. "Islamic Schools, the Ulama and the State in the Educational Development of Northern Nigeria." Bulletin de l'APAD 33. Accessed 21 October 2017. https://apad.revues.org/4092.

Bah-Lalya, I. 2015. "Koranic Education Centres: A Viable Educational Alternative for the Disadvantaged Learner in Sahel Africa?" International Review of Education 61(4): 465-479.

Bano, M. 2010. "Madrasas as Partners in Education Provision: The South Asian Experience." Development in Practice 20(4\&5): 554-66.

Bano, M. 2012. The Rational Believer: Choices and Decisions in the Madrasas of Pakistan. Ithaca, NY: Cornell University Press.

CUBE (Capacity for Universal Basic Education). 2008. Islamiyya, Quranic and Tsangaya Education (IQTE) Integration Strategy. Kano. Kano State Government/CUBE - DFID. 
Danladi-Saleh, G. 2016. "The night Boko Haram kidnapped our girls: a Chibok resident remembers." The Guardian, 14 April 2016. Accessed 20 February 2017. https://www.theguardian.com/world/2016/apr/14/the-night-boko-haram-kidnapped-our-girls$\underline{\text { a-chibok-resident-remembers }}$

Dang, H., L. Sarr, and N. Asadullah. 2011. "School Access, Resources, and Learning Outcomes: Evidence from a Non-formal School Program in Bangladesh.” IZA DP Working Paper No. 5659. Bonn: Institute for the Study of Labour.

ESSPIN (Education Sector Support Programme in Nigeria). 2011. "ESSPIN Experiences: Integrating Old with the New: Islamic Education Responds to the Demands of Modern Society.” ESSPIN Experience Paper. Accessed 21 October 2017.

http://www.camb-ed.com/Portals/0/Documents/ESSPIN-Experiences-Integrating-the-oldwith-the-new.pdf

ESSPIN (Education Sector Support Programme in Nigeria). 2014. "Introducing Modern Education into Islamic Schools in Northern Nigeria: A Report on ESSPIN's $1^{\text {st }}$ Phase Experience: 2008-2014.” ESSPIN Practice Paper.

Gee, K. A. 2015. “Achieving gender equality in learning outcomes: Evidence from a nonformal education program in Bangladesh.” International Journal of Educational Development 40: 207-216. 
GPE (Global Partnership for Education). 2014. "Conflict-affected and Fragile States." Global Partnership for Education. Accessed 11 January 2017.

http://www.globalpartnership.org/focus-areas/conflict-affected-and-fragile-states

GMR (Global Monitoring Report) and UIS (UNESCO Institute for Statistics). 2014.

"Progress in getting all children to school stalls but some countries show the way forward." UNESCO, Policy Paper 14/ Fact Sheet, 28, June 2014. Accessed 11 January 2017.

http://uis.unesco.org/sites/default/files/documents/fs28-progress-in-getting-all-children-toschool-stalls-but-some-countries-show-the-way-forward-2014-en.pdf

KERD (Kano Educational Resources Department). 2014. Official Primary Transition Exam Results. Kano: Ministry of Education.

MoE (Ministry of Education). 2010. Kano State Annual Education Sector Report 2010. Kano State: Federal Republic of Nigeria.

Mfum-Mensah, O. 2003. "Fostering educational participation in pastoral communities through non-formal education: the Ghanaian perspective." International Journal of Educational Development 23: 661-677.

Nath, S. R., K. Sylva, and J. Grimes. 1999. "Raising Basic Education Levels in Rural Bangladesh: The Impact of a Non-formal Education Programme." International Review of Education 45: 5-26. 
Rose, P. 2009. "Non-State Provision of Education: Evidence from Africa and Asia." Compare: A Journal of Comparative and International Education 39: 127-134.

Umar, A. S. 2001. "Education and Islamic Trends in Northern Nigeria." Africa Today 48(2): 127-150.

Umar, A. S. 2003. "Profiles of New Islamic schools in Northern Nigeria." The Maghreb Review 28(2-3): 146-169.

UNESCO (United Nations Educational Scientific and Cultural Organisation). 2006. Education for All Global Monitoring Report 2006. Paris: UNESCO.

UNESCO (United Nations Educational Scientific and Cultural Organisation). 2015. EFA Global Monitoring Report 2015. Paris: UNESCO.

UNICEF (United Nations Children's Fund). 2014. “Community-Based Schools Bring Hope to Afghanistan's Remote Settlements." UNICEF, 23 February 2007. Accessed 15 March 2017.

http://www.unicef.org/infobycountry/afghanistan_38434.html

UNICEF (United Nations Children's Fund). 2017. “Nigeria Country Profile.” UNICEF. Accessed 15 March 2017, https://www.unicef.org/nigeria/children_1941.html 
USAID (The United States Agency for International Development). 2012. "Meeting EFA:

Afghanistan Community Schools.” EQUIP2 Case Study. Accessed 15 January 2017.

http://pdf.usaid.gov/pdf_docs/PNADI076.pdf 